\title{
Both duration and degree of hypercalcemia influence the reduced parathyroid hormone response to hypocalcemia after hypercalcemia
}

\author{
S Bas, A Bas, Y Almadén ${ }^{1}$, E Ballesteros ${ }^{2}$, M Rodríguez ${ }^{1}$ \\ and $\mathbf{E}$ Aguilera-Tejero \\ Departamento de la Medicina y Cirugía Animal, Universidad de Córdoba, Campus de Rabanales, Ctra Madrid-Cádiz km 396,14014 Córdoba, Spain \\ ${ }^{1}$ Departamento de la Nefrología y Unidad de Investigación, Hospital Universitario Reina Sofía, Avda Menéndez Pidal s/n, 14004 Córdoba, Spain \\ ${ }^{2}$ Departamento de la Física y Química Analítica, Universidad de Jaén, Jaén, Spain \\ (Requests for offprints should be addressed to E Aguilera-Tejero; Email: pv1agtee@lucano.uco.es)
}

\begin{abstract}
The stimulation of parathyroid hormone (PTH) secretion by hypocalcemia is reduced when hypocalcemia is preceded by hypercalcemia. The present study investigates whether the duration and degree of hypercalcemia influence the reduced PTH response to hypocalcemia after hypercalcemia. In addition, the implication of the arachidonic acid (AA) signaling pathway in this effect is evaluated. The PTH response to hypocalcemia has been studied in a control group and in four groups of rabbits subjected to hypercalcemia for different periods of time (between 30 and $120 \mathrm{~min}$ ) and at two levels of hypercalcemia (1.9 and $2.1 \mathrm{mM})$. AA levels have been measured in parathyroid glands from rabbits subjected to hyper- and hypocalcemia. When compared with controls, rabbits that had been hypercalcemic $(2.1 \mathrm{mM})$ for $2 \mathrm{~h}$ showed a markedly attenuated PTH response to hypocalcemia (50\% of normal PTHmax), rabbits that had been in
\end{abstract}

hypercalcemia $(2.1 \mathrm{mM})$ for $75 \mathrm{~min}$ had an intermediate PTH response to hypocalcemia (70\% of normal PTHmax) and rabbits that had been subjected to either $30 \mathrm{~min}$ hypercalcemia of $2.1 \mathrm{mM}$ or $120 \mathrm{~min}$ hypercalcemia of $1.9 \mathrm{mM}$ had a normal PTH response to hypocalcemia. AA levels increased in hypercalcemia and decreased in hypocalcemia; however, no differences were observed at either calcium level in short-time (30 min) versus long-time (120 min) hypercalcemia. In conclusion, the attenuated PTH response to hypocalcemia after hypercalcemia is dependent on both the period of time that the parathyroid glands have been exposed to hypercalcemia and the degree of hypercalcemia. In addition, this reduced PTH response does not seem to be related to changes in the AA signaling pathway.

Journal of Endocrinology (2003) 177, 119-126

\section{Introduction}

A reduced parathyroid hormone (PTH) response to hypocalcemia after a short period of hypercalcemia has previously been reported in cows (Blum et al. 1981), dogs (Sanchez et al. 1996) and rabbits (Bas et al. 2002). Moreover, the PTH-calcium curve after hypercalcemia has been studied in detail in dogs and rabbits. In both studies the animals were subjected to a hypercalcemic clamp (blood $\mathrm{Ca}^{2+}$ was increased by $0.4 \mathrm{mM}$ ) for $2 \mathrm{~h}$ and then their parathyroid glands were stimulated by hypocalcemia. When compared with animals in which hypocalcemia was initiated from basal $\mathrm{Ca}^{2+}$ levels, the PTH response to hypocalcemia was less for the same concentration of $\mathrm{Ca}^{2+}$ when the reduction in $\mathrm{Ca}^{2+}$ was initiated from hypercalcemia compared with that from a normal plasma calcium concentration (Sanchez et al. 1996, Bas et al. 2002).

Since both prolonged (2 months) and very short (10 min) periods of hypercalcemia have been reported not to modify the PTH response to hypocalcemia (Blum et al. 1981, Bas et al. 2002), a time-frame should exist for the attenuation of the PTH response after hypercalcemia to take place. In addition, we hypothesize that the inhibitory effect of hypercalcemia on a subsequent hypocalcemic stimulus could also be related to the degree to which calcium is elevated.

The blunted PTH response to hypocalcemia after hypercalcemia may indicate that PTH secretion is disturbed but it could also be interpreted as a physiological mechanism - the parathyroid cells may have some kind of 'memory' which modulates their response in the face of previous events. The latter hypothesis is supported by other characteristics of the $\mathrm{PTH}-\mathrm{Ca}^{2+}$ relationship (e.g. hysteresis). The phenomenon of hysteresis is that, for the same $\mathrm{Ca}^{2+}$ level, PTH values are higher when inducing hypocalcemia than when recovering from hypocalcemia. Similarly, PTH concentrations are lower when inducing hypercalcemia than when recovering from hypercalcemia (Conlin et al. 1989, Grant et al. 1990). It has been 
suggested that the hysteresis of the $\mathrm{PTH}-\mathrm{Ca}^{2+}$ curve is a defence mechanism intended to foresee the future evolution of $\mathrm{Ca}^{2+}$ levels (Aguilera-Tejero et al. 1996).

The mechanisms by which hypercalcemia attenuates the PTH response to hypocalcemia are unknown. Hypercalcemia has been reported to modify PTH metabolism (Chu et al. 1973, Habener et al. 1975), to influence PTH gene transcription and to decrease PTH mRNA levels (Russel et al. 1983, Yamamoto et al. 1989). Hypercalcemia is also known to modify the secretory profile of PTH and its fragments - secretion of carboxyterminal PTH is less suppressed than secretion of intact PTH when extracellular $\mathrm{Ca}^{2+}$ is elevated (Mayer et al. 1979, Cloutier et al. 1992, 1994).

Since the reduced response to hypocalcemia is evident when the parathyroid glands have been exposed to hypercalcemia for only $2 \mathrm{~h}$ (Sanchez et al. 1996, Bas et al. 2002), it is likely that post-translational mechanisms are involved. We hypothesize that changes in intracellular sensing mechanisms triggered by the action of $\mathrm{Ca}^{2+}$ on the calcium receptor $(\mathrm{CaR})$ could explain this phenomenon. We and others have shown that the phospholipase $\mathrm{A}_{2}-$ arachidonic acid ( $\left.\mathrm{PLA}_{2}-\mathrm{AA}\right)$ pathway is a key signaling system which mediates the inhibition of $\mathrm{PTH}$ secretion in response to increases in extracellular $\mathrm{Ca}^{2+}$ (Bourdeau et al. 1992, Almaden et al. 2002). Therefore, AA is a likely candidate to be involved in the attenuation of the PTH response after hypercalcemia.

The objectives of the work reported here were (1) to determine the time of exposure to hypercalcemia required to observe a reduced PTH response to hypocalcemia; (2) to investigate the degree of hypercalcemia (i.e. the elevation in extracellular $\mathrm{Ca}^{2+}$ ) necessary to elicit a reduced PTH response to hypocalcemia; and (3) to study the influence that an intracellular signaling pathway (AA) may have on the reduced PTH response to hypocalcemia after hypercalcemia.

\section{Materials and Methods}

\section{Animals}

White New Zealand rabbits of both sexes, aged 9-15 months and weighing $3 \cdot 8 \pm 0 \cdot 1 \mathrm{~kg}$, where used in the experiments. Rabbits were housed individually, had free access to water, and a commercial diet containing $1 \cdot 2 \% \mathrm{Ca}$ and $0 \cdot 6 \% \mathrm{P}$ was available ad libitum. The rabbits were randomly assigned to any of the following groups. Group I $(n=10)$ : these animals were used as a control to obtain the PTH- $\mathrm{Ca}^{2+}$ curve in normocalcemic rabbits (plasma $\left.\mathrm{Ca}^{2+}=1.7 \mathrm{mM}\right)$. Group II $(n=10)$ : in this group plasma $\mathrm{Ca}^{2+}$ was progressively increased from its baseline value of $1.7 \mathrm{mM}$ to $2.1 \mathrm{mM}$ during a period of $30 \mathrm{~min}$. Immediately after reaching $2 \cdot 1 \mathrm{mM}$, calcium was progressively decreased to a level below $1 \mathrm{mM}$ during a 60 -min period. Group III $(n=9)$ : in these rabbits, plasma $\mathrm{Ca}^{2+}$ was increased from its baseline value $(1.7 \mathrm{mM})$ to $2.1 \mathrm{mM}$ during the first $30 \mathrm{~min}$ and then was maintained elevated for an additional period of $45 \mathrm{~min}$. Subsequently hypocalcemia was induced as in group II. Group IV $(n=9)$ : hypercalcemia was induced as in groups II and III but the hypercalcemic clamp was extended to a period of $90 \mathrm{~min}$ before the hypocalcemic stimulation. Group V $(n=7)$ : these rabbits were also subjected to a 90-min hypercalcemic clamp but plasma $\mathrm{Ca}^{2+}$ was elevated only $0.2 \mathrm{mM}$. Thus, during the first $30 \mathrm{~min}$ plasma $\mathrm{Ca}^{2+}$ was raised from $1.7 \mathrm{mM}$ to $1.9 \mathrm{mM}$, and then was clamped for an additional $90 \mathrm{~min}$ at $1.9 \mathrm{mM}$. Subsequently, hypocalcemia was induced as in groups II-IV.

Five additional experimental groups were studied to determine AA production by parathyroid tissue. Group VI $(n=5)$ : in these rabbits plasma $\mathrm{Ca}^{2+}$ was elevated as in group II. At the end of $30 \mathrm{~min}$ hypercalcemia, the parathyroid glands were removed. Group VII $(n=5)$ : these rabbits were subjected to hypercalcemia for $30 \mathrm{~min}$, followed by $60 \mathrm{~min}$ hypocalcemia (as in group II). At the end of the hypocalcemic stimulation, parathyroidectomy was performed. Group VIII $(n=6)$ : in these rabbits plasma $\mathrm{Ca}^{2+}$ was elevated following the same protocol as in group IV and at the end of the 90-min hypercalcemic clamp the parathyroid glands were removed. Group IX $(n=5)$ : rabbits followed the same protocol as group IV and parathyroidectomy was performed at the end of the 60-min hypocalcemic stimulus. Group $\mathrm{X}(n=7)$ : these rabbits served as a control group for AA content in parathyroid tissue; the parathyroid glands were obtained without modifying plasma $\mathrm{Ca}^{2+}$.

PTH-Ca ${ }^{2+}$ curves

$\mathrm{PTH}-\mathrm{Ca}^{2+}$ curves were obtained by i.v. infusion of disodium EDTA. In all experimental groups, rabbits were anesthetized using a single dose of ketamine $(40 \mathrm{mg} / \mathrm{kg})$ and midazolam $(1 \mathrm{mg} / \mathrm{kg})$ administered before starting the experiments. Rabbits in groups IV, V, VIII and IX received an additional dose of ketamine $(20 \mathrm{mg} / \mathrm{kg})$ and midazolam $(0.5 \mathrm{mg} / \mathrm{kg})$ at $100 \mathrm{~min}$ to prolong anesthesia until the end of the experiments. The marginal auricular vein and the central auricular artery were cannulated with $24 \mathrm{G}$ catheters. The venous port was used for $\mathrm{CaCl}_{2}$ and EDTA infusion and the arterial side for blood sampling. The protocols for induction of hyper- and hypocalcemia are set out below.

Hypercalcemia In groups II, III, IV, VI, VII, VIII and IX, hypercalcemia was achieved by i.v. infusion of $\mathrm{CaCl}_{2}$ at a mean rate of $1.5 \mathrm{mEq} / \mathrm{kg} / \mathrm{h}$ during $30 \mathrm{~min}$. When a calcium clamp was performed, hypercalcemia was maintained by infusing $\mathrm{CaCl}_{2}$ at a rate of $1.2 \mathrm{mEq} / \mathrm{kg} / \mathrm{h}$ during $45 \mathrm{~min}$ (group III) or $90 \mathrm{~min}$ (groups IV, VIII and IX). In group $\mathrm{V}$, hypercalcemia was induced during $30 \mathrm{~min}$ and 
maintained during $90 \mathrm{~min}$ by infusing $0.75 \mathrm{mEq} / \mathrm{kg} / \mathrm{h}$ of $\mathrm{CaCl}_{2}$.

Hypocalcemia In group I, hypocalcemia was induced by an EDTA infusion which was initiated at a rate of $50 \mathrm{mg} / \mathrm{kg} / \mathrm{h}$. To achieve a linear decrease in $\mathrm{Ca}^{2+}$, the rate of the EDTA infusion was progressively increased every $5 \mathrm{~min}$, up to $190 \mathrm{mg} / \mathrm{kg} / \mathrm{h}$ at the end of the experiment (35 min). In groups II, III, IV, VI, VII, VIII and IX, hypocalcemia was induced, first by reducing the dose of $\mathrm{CaCl}_{2}$ during $15 \mathrm{~min}$ and then by infusing EDTA at an initial rate of $25 \mathrm{mg} / \mathrm{kg} / \mathrm{h}$ which was progressively increased to $240 \mathrm{mg} / \mathrm{kg} / \mathrm{h}$ at the end of the experiment (60 min). In group $\mathrm{V}$, hypocalcemia was achieved, first by reducing the dose of $\mathrm{CaCl}_{2}$ over a $10-\mathrm{min}$ period and then by EDTA infusion starting at $25 \mathrm{mg} / \mathrm{kg} / \mathrm{h}$ and finishing at $180 \mathrm{mg} / \mathrm{kg} / \mathrm{h}$.

To avoid interference associated with volume loading, the rate of administration of fluids was adjusted to be identical in all groups during induction of hyper- and hypocalcemia. During the hypercalcemic clamp volume infusion rates were also very similar ranging from $0.06 \mathrm{ml} / \mathrm{kg} / \mathrm{min}$ (group V) to $0.07 \mathrm{ml} / \mathrm{kg} / \mathrm{min}$ (group III). Moreover, the sodium load was identical in all experimental groups.

Three blood samples were obtained from each animal as baseline; thereafter, blood samples were collected every 5 min until the end of the experiments. Samples were immediately centrifuged. Plasma was separated and $\mathrm{Ca}^{2+}$ and $\mathrm{pH}$ were measured using selective electrodes (Bayer Diagnostics, Barcelona, Spain) after which plasma was frozen at $-70{ }^{\circ} \mathrm{C}$. PTH was measured on plasma samples within 3 months of collection using an immunoradiometric assay (Allegro Intact PTH, Nichols, San Juan Capistrano, CA, USA) which has previously been validated for quantitation of rabbit PTH (Warren et al. 1989). Plasma phosphate and magnesium concentrations were measured using routine spectrophotometric techniques (Sigma, St Louis, MO, USA).

During the experiments, blood samples were obtained at predetermined time intervals. Since $\mathrm{Ca}^{2+}$ values were not identical in all rabbits at the time of sampling, the following procedure was used to obtain the $\mathrm{PTH}-\mathrm{Ca}^{2+}$ curve at standardized $\mathrm{Ca}^{2+}$ levels (Aguilera-Tejero et al. 1996, Bas et al. 2002). First, individual PTH- $\mathrm{Ca}^{2+}$ curves were constructed by adjusting the $\mathrm{PTH}$ and $\mathrm{Ca}^{2+}$ values of every rabbit to a sigmoidal equation. The PTH values used for the hypercalcemic part of the curve were those recorded during the hypocalcemic stimulation (when calcium was decreased from 2.1 or $1.9 \mathrm{mM}$ to $1.7 \mathrm{mM}$ ). The PTH concentrations at standardized $\mathrm{Ca}^{2+}$ levels (from $\mathrm{Ca}^{2+}=2 \cdot 1 \mathrm{mM}$ to $\mathrm{Ca}^{2+}=1 \mathrm{mM}$, with an interval of $0.05 \mathrm{mM}$ ) were extrapolated from these individual curves. Mean PTH values at standardized $\mathrm{Ca}^{2+}$ concentrations were used to obtain the $\mathrm{PTH}-\mathrm{Ca}^{2+}$ curve for each group.

\section{AA measurement}

AA was measured in parathyroid tissue. Rabbits from groups VI-X were anesthetized as described above. In groups VI-IX hyper- or hypocalcemia was induced using the above mentioned protocols. The external parathyroid glands were surgically exposed and were then carefully removed without thyroid tissue. The time required to complete parathyroidectomy was less than 5 min.

Glands were dissected free of fat and connective tissue and were placed in individual wells submerged in ice. Parathyroid tissue was homogenized with a glass homogenizer in a solution containing $50 \mathrm{mM}$ Tris- $\mathrm{HCl}$ $\left(\mathrm{pH} 7.5\right.$ at $25^{\circ} \mathrm{C}$ ), $0.2 \mathrm{mM}$ EDTA, and $0.5 \mathrm{mM}$ dithiothreitol. AA was quantified by gas chromatography (model 5890-A; Hewlett Packard, Avondale, PA, USA) as described elsewhere (Cardenas et al. 1994). The coefficient of variation for AA quantification was $2 \cdot 5 \%$. The protein content of the tissue samples was determined using the Bradford method (Bradford 1976).

\section{Statistics}

For the intra- or intergroup comparison of three or more samples, repeated analysis of variance (ANOVA) was used. If the ANOVA showed statistical differences, a post hoc test, the Scheffe test, was used to determine differences. A $P$ value $<0.05$ was considered significant. Results are expressed as the mean \pm S.E.

\section{Results}

$\mathrm{Ca}^{2+}$ and PTH values

The time course for plasma $\mathrm{Ca}^{2+}$ and PTH in groups I, II, III, IV and $\mathrm{V}$ is presented in Fig. 1. No significant differences in baseline $\mathrm{Ca}^{2+}$ were detected between groups. In groups II- $-\mathrm{Ca}^{2+}$ was elevated as scheduled. Thus $\mathrm{Ca}^{2+}$ values before induction of hypocalcemia were $2 \cdot 12 \pm 0.03 \mathrm{mM}$ (group II), $2.13 \pm 0.06 \mathrm{mM}$ (group III), $2.08 \pm 0.02 \mathrm{mM}$ (group IV) and 1.88 $\pm 0.02 \mathrm{mM}$ (group V). All these $\mathrm{Ca}^{2+}$ levels were significantly higher than baseline. In rabbits from group $\mathrm{V}$ the $\mathrm{Ca}^{2+}$ concentration before induction of hypocalcemia $(1.88 \pm 0.02 \mathrm{mM})$ was lower $(P<0 \cdot 05)$ than in groups II-IV. During hypocalcemia there was a parallel decrease in $\mathrm{Ca}^{2+}$ in all groups, reaching final values that ranged between 0.96 and 1.09 mM (Fig. 1A).

No significant differences were found in baseline PTH in groups I-V. Hypercalcemia resulted in a decrease in PTH concentration and the values measured before starting hypocalcemia were: $5 \cdot 7 \pm 0.6 \mathrm{pg} / \mathrm{ml}$ (group II), $2.9 \pm 1 \cdot 1 \mathrm{pg} / \mathrm{ml}$ (group III), $4 \cdot 8 \pm 0.9 \mathrm{pg} / \mathrm{ml}$ (group IV) and $10 \cdot 6 \pm 2 \cdot 3 \mathrm{pg} / \mathrm{ml}$ (group V). All these values were significantly lower than baseline and the PTH value in group $\mathrm{V}$ was higher than in groups II-IV $(P<0 \cdot 05)$. 

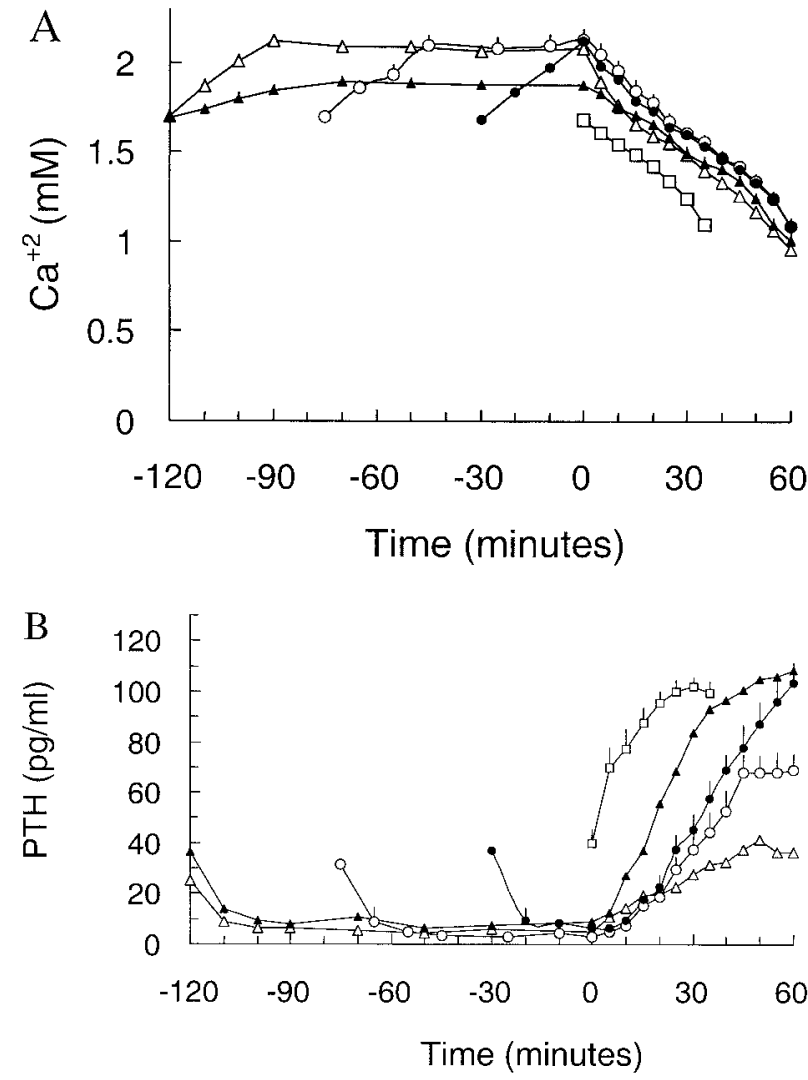

Figure 1 The time course of (A) $\mathrm{Ca}^{2+}$ and (B) PTH in groups I to V. Values are means \pm S.E. (when the standard error bar is not present, it was too small to draw). Group I, normocalcemic rabbits ( $\square$ ); group II, rabbits subjected to 30 min hypercalcemia, $2 \cdot 1 \mathrm{mM}$ (-); group III, rabbits subjected to a 45-min hypercalcemic clamp, $2 \cdot 1 \mathrm{mM}(\mathrm{O})$; group IV, rabbits subjected to a 90-min hypercalcemic clamp, $2 \cdot 1 \mathrm{mM}(\triangle)$; group $\mathrm{V}$, rabbits subjected to a 90-min hypercalcemic clamp, $1.9 \mathrm{mM}(\boldsymbol{\Delta})$.

During hypocalcemia PTH concentration rose in group I to a maximum (PTHmax) of $99 \cdot 7 \pm 4 \cdot 2 \mathrm{pg} / \mathrm{ml}$. PTHmax in groups II $(103 \cdot 3 \pm 7 \cdot 6 \mathrm{pg} / \mathrm{ml})$ and V $(108 \cdot 3 \pm 9 \cdot 2 \mathrm{pg} /$ $\mathrm{ml}$ ) was not different from group I. Rabbits from group III had a PTHmax $(68.7 \pm 8 \cdot 1 \mathrm{pg} / \mathrm{ml})$ which was lower $(P<0 \cdot 05)$ than groups I, II and V. Finally the PTHmax in group IV was significantly lower $(36 \cdot 4 \pm 7 \cdot 6 \mathrm{pg} / \mathrm{ml})$ than in all the other groups (Fig. 1B).

A summary of the changes in $\mathrm{Ca}^{2+}$ and $\mathrm{PTH}$ in the experimental groups I, II, III, IV and V is shown in Table 1.

Phosphate and magnesium concentrations are presented in Table 2. Mean baseline P in all groups ranged from 1.23 to $1.28 \mathrm{mM}$ and did not change in any group throughout the experiments. Mean baseline $\mathrm{Mg}$, which ranged from 0.97 to $0.99 \mathrm{mM}$, did not change during any of the protocols for induction of hypercalcemia. EDTA infusion resulted in a progressive decrease in $\mathrm{Mg}$ that was parallel to the decline in $\mathrm{Ca}^{2+}$. Changes in $\mathrm{Mg}$ during EDTA administration were similar in all experimental groups.

\section{$\mathrm{PTH}-\mathrm{Ca}^{2+}$ curves}

The $\mathrm{PTH}-\mathrm{Ca}^{2+}$ curves in groups $\mathrm{I}-\mathrm{V}$ are shown in Fig. 2. In group I, at baseline $\mathrm{Ca}^{2+}$ of $1.7 \mathrm{mM}$, the PTH concentration was $40 \cdot 1 \pm 5 \cdot 3 \mathrm{pg} / \mathrm{ml}$. Hypocalcemia caused an increase in PTH concentration up to a maximun of $103 \cdot 1 \pm 3 \cdot 2 \mathrm{pg} / \mathrm{ml}$ which was achieved with a $\mathrm{Ca}^{2+}$ concentration of $1.25 \mathrm{mM}$. PTH values remained stabilized at $\mathrm{Ca}^{2+}$ levels between 1.25 and $1 \mathrm{mM}$. In groups II, III and IV in which the hypocalcemic stimulus was initiated from hypercalcemia, the minimal PTH concentration was recorded at a $\mathrm{Ca}^{2+}$ concentration of $2 \cdot 1 \mathrm{mM}$. At this $\mathrm{Ca}^{2+}$ level, PTH values were below $5 \mathrm{pg} / \mathrm{ml}$ and no significant differences were found between groups. In the hypocalcemic part of the curve, no significant differences between groups I and II were found at any $\mathrm{Ca}^{2+}$ concentration. In group III, PTH values were significantly lower than in group I at all $\mathrm{Ca}^{2+}$ values below $1.6 \mathrm{mM}$. PTH values in group IV were significantly lower than in groups I and II at all $\mathrm{Ca}^{2+}$ values below $1.65 \mathrm{mM}$. In addition, PTH values at $\mathrm{Ca}^{2+}$ levels below $1.65 \mathrm{mM}$ were lower in group IV than in group III $(P<0 \cdot 05)$. The $\mathrm{PTH}-\mathrm{Ca}^{2+}$ curve in group $\mathrm{V}$ shows that $\mathrm{PTH}$ values during hypercalcemia (between $\mathrm{Ca}^{2+} 1.7$ and $1.85 \mathrm{mM}$ ) were similar to groups II and III. At any $\mathrm{Ca}^{2+}$ concentration between 1.7 and $1 \mathrm{mM}$, PTH levels were almost identical in groups I and V.

Table 1 Summary of $\mathrm{Ca}^{2+}$ and PTH values in the experimental groups I to $\mathrm{V}$

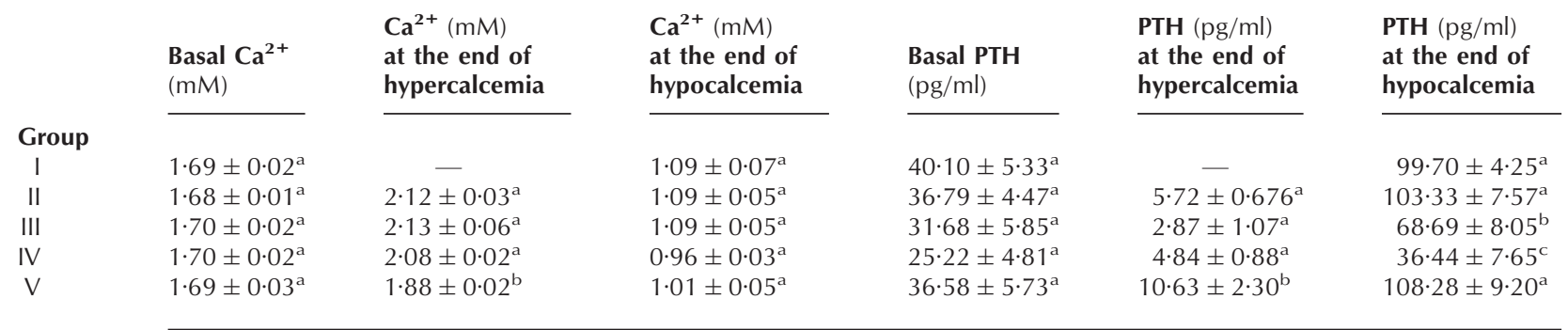


Table 2 Summary of phosphate $(\mathrm{P})$ and magnesium $(\mathrm{Mg})$ values in the experimental groups I to $\mathrm{V}$

\begin{tabular}{|c|c|c|c|c|c|c|}
\hline & $\begin{array}{l}\text { Basal P } \\
(\mathrm{mM})\end{array}$ & $\begin{array}{l}\mathbf{P}(\mathrm{mM}) \\
\text { at the end of } \\
\text { hypercalcemia }\end{array}$ & $\begin{array}{l}\mathbf{P}(\mathrm{mM}) \\
\text { at the end of } \\
\text { hypocalcemia }\end{array}$ & $\begin{array}{l}\text { Basal Mg } \\
(\mathrm{mM})\end{array}$ & $\begin{array}{l}\mathrm{Mg}(\mathrm{mM}) \\
\text { at the end of } \\
\text { hypercalcemia }\end{array}$ & $\begin{array}{l}\mathrm{Mg}(\mathrm{mM}) \\
\text { at the end of } \\
\text { hypocalcemia }\end{array}$ \\
\hline \multicolumn{7}{|c|}{ Group } \\
\hline I & $1 \cdot 23 \pm 0 \cdot 09$ & - & $1 \cdot 31 \pm 0 \cdot 09$ & $0.99 \pm 0.05$ & - & $0 \cdot 41 \pm 0 \cdot 04^{a}$ \\
\hline II & $1 \cdot 24 \pm 0 \cdot 12$ & $1 \cdot 29 \pm 0 \cdot 11$ & $1 \cdot 30 \pm 0 \cdot 16$ & $0.98 \pm 0.04$ & $0.99 \pm 0.04$ & $0 \cdot 43 \pm 0 \cdot 05^{\mathrm{a}}$ \\
\hline III & $1 \cdot 27 \pm 0.09$ & $1 \cdot 23 \pm 0 \cdot 12$ & $1 \cdot 30 \pm 0 \cdot 11$ & $0.98 \pm 0.05$ & $0.99 \pm 0.05$ & $0.47 \pm 0.05^{a}$ \\
\hline IV & $1 \cdot 28 \pm 0 \cdot 05$ & $1 \cdot 28 \pm 0.05$ & $1 \cdot 26 \pm 0.07$ & $0.97 \pm 0.06$ & $1.00 \pm 0.08$ & $0.47 \pm 0.06^{a}$ \\
\hline V & $1 \cdot 28 \pm 0.08$ & $1.29 \pm 0.05$ & $1 \cdot 26 \pm 0.07$ & $0.98 \pm 0.07$ & $0.97 \pm 0.04$ & $0 \cdot 40 \pm 0.05^{\mathrm{a}}$ \\
\hline
\end{tabular}

No significant differences between groups were found at any sampling time. ${ }^{a} P<0 \cdot 05$ when compared with baseline.

As described above, the PTH values used to construct the PTH-Ca ${ }^{2+}$ curves in groups II-V were those obtained during hypocalcemic stimulation from hypercalcemia. However, in the hypercalcemic part of the PTH- $\mathrm{Ca}^{2+}$ curve two sets of PTH values were recorded for each $\mathrm{Ca}^{2+}$ concentration - PTH during induction of hypercalcemia from normocalcemia (first $30 \mathrm{~min}$ of experiment) and PTH during induction of hypocalcemia from hypercalcemia (last $60 \mathrm{~min}$ of experiment). These two sets of PTH values are shown in Fig. 3. In rabbits from groups II and V, PTH values during recovery from hypercalcemia were higher than PTH values during induction of hypercalcemia $\left(P<0.05\right.$ at $\left.\mathrm{Ca}^{2+}=1.8 \mathrm{mM}\right)$, i.e. hysteresis of the $\mathrm{PTH}-\mathrm{Ca}^{2+}$ curve was observed (Fig. $3 \mathrm{~A}$ and B). However, in rabbits from groups III and IV no difference was found between PTH values during induction of and recovery from hypercalcemia (Fig. 3C and D).

\section{AA measurements}

AA levels in the parathyroid glands of rabbits in groups VI-X are presented in Fig. 4. AA production by

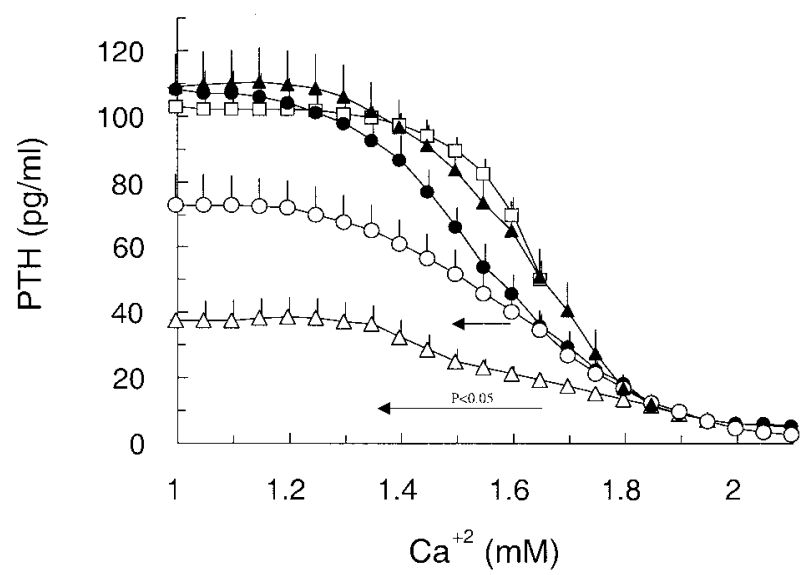

Figure 2 The $\mathrm{PTH}-\mathrm{Ca}^{2+}$ curve in groups I-V. Values are means \pm S.E. (when the standard error bar is not present, it was too small to draw). Where the arrows start indicates that PTH values are significantly lower than the PTH concentration registered in group I for the same $\mathrm{Ca}^{2+}$ level. Group I ( $\square$ ); group II $(\bullet)$; group III $(\bigcirc)$; group IV $(\triangle)$; group $\mathrm{V}(\mathbf{\Delta})$. parathyroid tissue was significantly higher $(P=0.03)$ during hypercalcemia (group VI $=9.2 \pm 2.3 \times 10^{-2} \mu \mathrm{g} / \mu \mathrm{g}$ protein and group VIII $=7.5 \pm 1.7 \times 10^{-2} \mu \mathrm{g} / \mu \mathrm{g}$ protein) than during hypocalcemia (group VII $=3.9 \pm 0.9 \times$ $10^{-2} \mu \mathrm{g} / \mu \mathrm{g}$ protein, group IX $=2.4 \pm 0.5 \times 10^{-2} \mu \mathrm{g} / \mu \mathrm{g}$ protein). No significant differences were detected between groups VI and VIII or between groups VII and IX. Normocalcemic rabbits had intermediate AA levels (group $\mathrm{X}=6.6 \pm 1.4 \times 10^{-2} \mu \mathrm{g} / \mu \mathrm{g}$ protein) in their parathyroid glands (Fig. 4A).

As illustrated in Fig. 4B, in the rabbits in which AA was measured, plasma PTH concentration changed as described above for groups II and IV. Thus, at elevated $\mathrm{Ca}^{2+}(2 \cdot 1 \mathrm{mM})$ PTH values were very low and similar in groups VI $(5 \cdot 7 \pm 0 \cdot 7 \mathrm{pg} / \mathrm{ml})$ and VIII $(4 \cdot 7 \pm 0 \cdot 7 \mathrm{pg} / \mathrm{ml})$. Decreasing $\mathrm{Ca}^{2+}$ concentration resulted in an increase in PTH levels. At low $\mathrm{Ca}^{2+}(1 \mathrm{mM})$, there was a significant difference in PTH values between groups VII $(103 \cdot 3 \pm 7 \cdot 6 \mathrm{pg} / \mathrm{ml})$ and IX $(38 \cdot 3 \pm 5 \cdot 6 \mathrm{pg} / \mathrm{ml})$.

\section{Discussion}

The objective of the present study was to investigate the circumstances that influence the reduced PTH response to hypocalcemia after the parathyroid glands have been subjected to hypercalcemia. Our results show that the attenuated PTH response to hypocalcemia is dependent on both the time the parathyroid glands have been exposed to hypercalcemia and the degree of hypercalcemia. In addition, this reduced PTH response does not seem to be related to changes in the AA signaling pathway.

The $\mathrm{PTH}-\mathrm{Ca}^{2+}$ curve obtained in normal rabbits is similar to that which has previously been reported elsewhere (Warren et al. 1989; Bas et al. 2002). Likewise, the 90-min hypercalcemic clamp resulted in an attenuated PTH response to hypocalcemia, comparable to that which has previously been described in dogs and rabbits $(50 \%$ decrease in PTHmax) (Sanchez et al. 1996, Bas et al. 2002). The 45-min hypercalcemic clamp resulted in a PTH response that was intermediate between those of rabbits in which hypocalcemia was initiated from normal $\mathrm{Ca}^{2+}$ and rabbits that had been subjected to a 90-min 

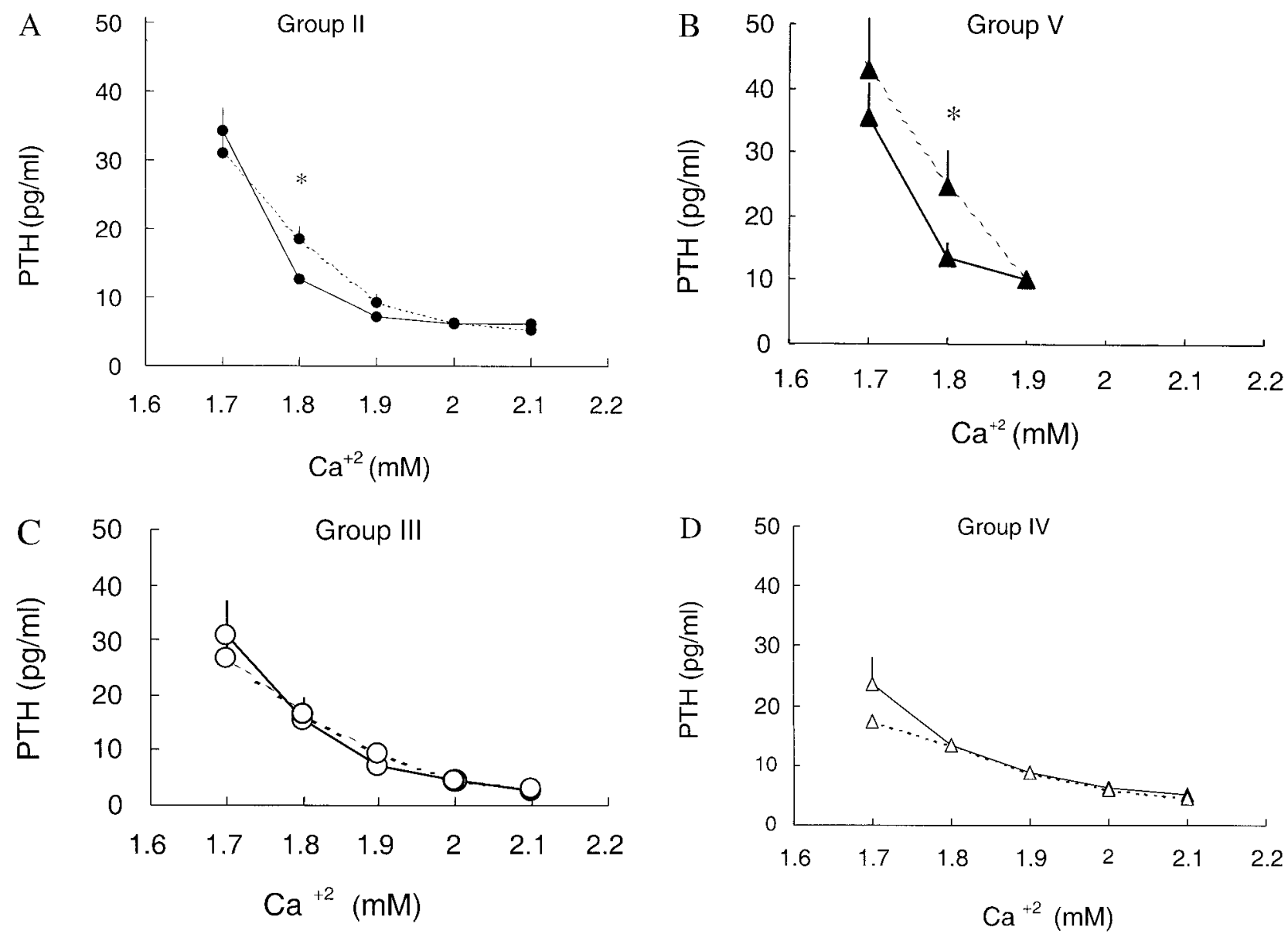

Figure 3 The PTH- $\mathrm{Ca}^{2+}$ curve in groups II (A), V (B), III (C) and IV (D) during induction of (solid line) and recovery from (dashed line) hypercalcemia. ${ }^{*} P<0.05$ significant differences in PTH concentration, for the same $\mathrm{Ca}^{2+}$ value, during induction of and recovery from hypercalcemia.

hypercalcemic clamp. The PTHmax of these rabbits was approximately $70 \%$ of the PTHmax of normal rabbits. Induction of hypercalcemia in the $30 \mathrm{~min}$ prior to the hypocalcemic stimulus did not modify the PTH response to hypocalcemia.

These results indicate that an attenuated PTH response to hypocalcemia requires more than $30 \mathrm{~min}$ of hypercalcemia, and the longer the time in hypercalcemia the more attenuated the PTH response to hypocalcemia. However, this process must show an inflexion at some time point, since it has also been demonstrated that rabbits become adapted to chronic ( 2 months) hypercalcemia and that the PTH- $\mathrm{Ca}^{2+}$ curve in chronic hypercalcemic rabbits is almost identical to the $\mathrm{PTH}-\mathrm{Ca}^{2+}$ curve in normal rabbits (Bas et al. 2002).

The period of time in hypercalcemia is not the only factor involved in the attenuation of the subsequent response to hypocalcemia, since in parathyroid glands exposed for $90 \mathrm{~min}$ to $\mathrm{Ca}^{2+}$ levels of $1.9 \mathrm{mM}$ (only $0 \cdot 2 \mathrm{mM}$ increase over basal $\mathrm{Ca}^{2+}$ ) there was no reduced
PTH response to hypocalcemia. Thus, $\mathrm{Ca}^{2+}$ needs to be increased by $>0.2 \mathrm{mM}$ to observe a decrease in the PTH response to hypocalcemia.

During EDTA infusion there was a progressive decrease in $\mathrm{Mg}$ that was parallel to the decline in $\mathrm{Ca}^{2+}$. Although hypomagnesemia is known to stimulate PTH secretion, the decrease in $\mathrm{Mg}$ at a time when the parathyroid cells are subjected to a much more potent stimulus (hypocalcemia) does not influence the PTH response (López 2002). In addition, changes in $\mathrm{Mg}$ were similar in all groups and therefore cannot explain the differences found in the PTH response.

It is known that for the same $\mathrm{Ca}^{2+}$ level PTH values are higher when recovering from hypercalcemia than when inducing hypercalcemia - hysteresis of the PTH- $\mathrm{Ca}^{2+}$ curve (Conlin et al. 1989, Grant et al. 1990). In their studies Conlin et al. and Grant et al. increased the plasma $\mathrm{Ca}^{2+}$ by $0.15 \mathrm{mM}$ during $90 \mathrm{~min}$ in healthy humans and recorded higher PTH values in the subsequent hypocalcemia than those measured during induction of 

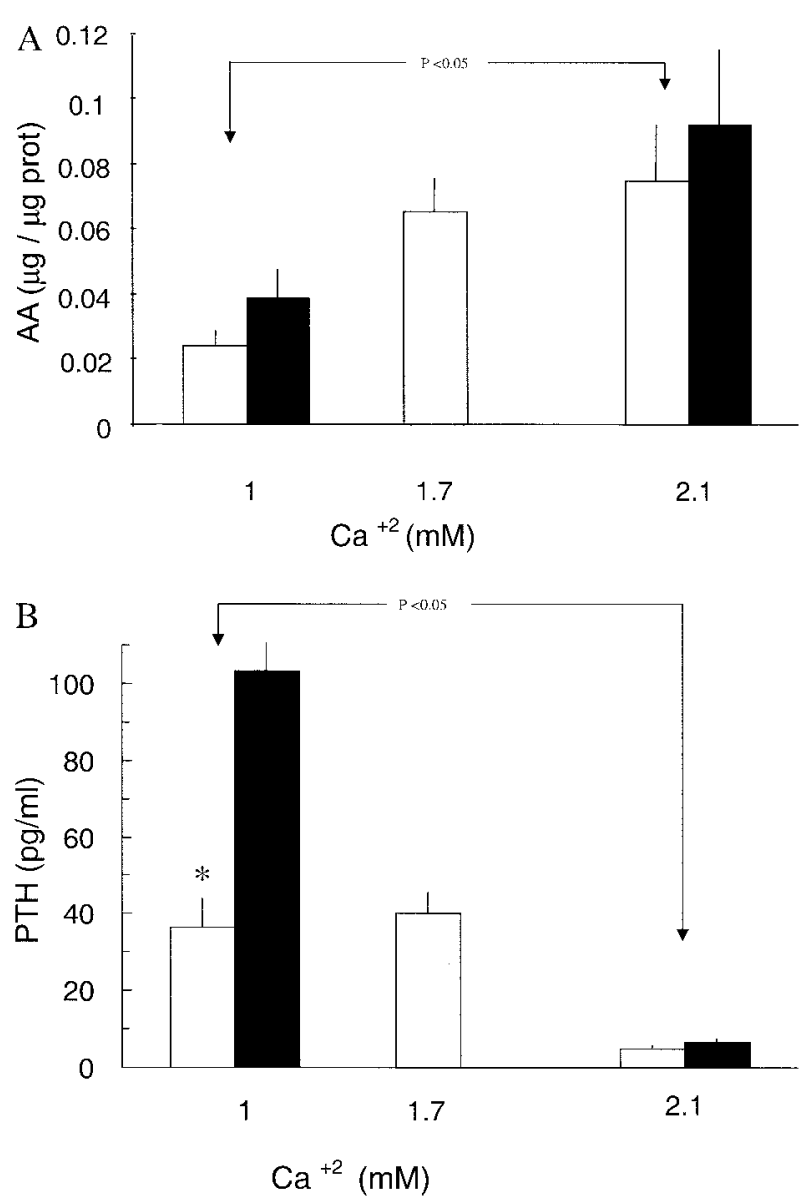

Figure 4 (A) Arachidonic acid (AA) content (in $\mu \mathrm{g} / \mu \mathrm{g}$ protein) in parathyroid tissue from rabbits at three levels of extracellular $\mathrm{Ca}^{2+}$ (B) Plasma PTH concentration (in $\mathrm{pg} / \mathrm{ml}$ ) in rabbits at three levels of extracellular $\mathrm{Ca}^{2+} .{ }^{*} P<0 \cdot 05$, significant differences between rabbits subjected to short-time hypercalcemia and to a hypercalcemic clamp. Solid bars indicate rabbits subjected to hypercalcemia for 30 min (groups VI and VII) and open bars indicate rabbits subjected to a 90-min hypercalcemic clamp (groups VIII and IX). Gray bars indicate rabbits in which plasma $\mathrm{Ca}^{2+}$ was not modified (group X).

hypercalcemia. The same phenomenon was observed in our study in group $\mathrm{V}$, where $\mathrm{Ca}^{2+}$ was elevated by only $0.2 \mathrm{mM}$ for $120 \mathrm{~min}$, and, to a lesser extent, in group II, where $\mathrm{Ca}^{2+}$ was elevated by $0.4 \mathrm{mM}$ for only $30 \mathrm{~min}$. However, in groups III and IV, where $\mathrm{Ca}^{2+}$ was increased by $0.4 \mathrm{mM}$ during 75 and $120 \mathrm{~min}$ respectively, no hysteresis was recorded. Thus, hysteresis of the PTH- $\mathrm{Ca}^{2+}$ curve seems to be dependent on both the level to which $\mathrm{Ca}^{2+}$ is elevated and the time elapsed in hypercalcemia.

It is also interesting to point out that the PTH response to hypocalcemia in the hypercalcemic range of the PTH$\mathrm{Ca}^{2+}$ curve seems to be related to the final PTH response to hypocalcemia - hysteresis was only found in the two groups (II and V) that reached the same PTHmax asthe control group. However, this situation is somewhat different in chronic hypercalcemia. Rabbits subjected to hypercalcemia for 2 months have been shown to have the same PTHmax in response to hypocalcemic stimulation as normal rabbits; however, no hysteresis was found in the hypercalcemic part of their PTH- $\mathrm{Ca}^{2+}$ curve (Bas et al. 2002).

The reasons for the reduced PTH response to hypocalcemia after a relatively short period of hypercalcemia are not clear. Hypercalcemia has been shown to inhibit PTH biosynthesis (Russell et al. 1983, Yamamoto et al. 1989). However, the rapid regulation described in this paper is probably best explained by changes in the amount of PTH available for secretion, which is controlled by a $\mathrm{Ca}^{2+}-$ dependent degradation process. High levels of extracellular $\mathrm{Ca}^{2+}$ have been shown to promote intracellular PTH degradation both in vivo (Chu et al. 1973) and in vitro (Habener et al. 1975); thus an increase in intracellular PTH metabolism could be a major factor in the reduced PTH response to hypocalcemia found in groups III and IV. It has also been speculated that secretory products could modify the PTH response to changes in plasma $\mathrm{Ca}^{2+}$. In this context, it has been shown that during hypercalcemia secretion of intact PTH(1-84) is suppressed while secretion of carboxyterminal PTH is less suppressed (Mayer et al. 1979, Cloutier et al. 1992, 1994). In addition to the secretion of intact PTH and its fragments, several secretory products of the parathyroid glands such as chromogranin A and its metabolites (Fasciotto et al. 1989, Drees \& Hamilton 1992, Ritchie et al. 1992) and endothelin 1 (Fujii et al. 1991) could play a role in the inhibition of PTH secretion after acute hypercalcemia.

Any kind of post-transcriptional regulation that would serve to explain the inhibitory effect of hypercalcemia on a subsequent hypocalcemic stimulus should be related to changes in intracellular signaling mechanisms triggered by the action of $\mathrm{Ca}^{2+}$ on the CaR. In this context, $\mathrm{AA}$ participates in a major signaling pathway within the parathyroid glands (Bourdeau et al. 1992, Almaden et al. 2000, 2002). Our results show predictable changes in AA concentration in the parathyroid glands with hypo- and hypercalcemia, AA levels being significantly increased during hypercalcemia when compared with hypocalcemia. However, the disparate PTH response to hypocalcemia after short-time $(30 \mathrm{~min})$ and long-time (120 min) hypercalcemia cannot be explained by changes in AA content in the parathyroid glands. Thus, it appears that changes in signal transduction via the $\mathrm{PLA}_{2}-\mathrm{AA}$ pathway are not the reason for the uneven PTH response to hypocalcemia after different periods of time in hypercalcemia.

In conclusion, the attenuated PTH response to hypocalcemia after hypercalcemia is dependent on both the time the parathyroid glands have been exposed to hypercalcemia and the degree of hypercalcemia. In addition, this reduced PTH response does not seem to be related to changes in AA concentration. 


\section{Acknowledgements}

This work was supported by grants BFI2001-1901 and BFI2001-0350 from the Ministerio de Ciencia y Tecnología, the Plan Andaluz de Investigación (Grupo CTS-179) and the Fundación Reina Sofia-Cajasur.

\section{References}

Aguilera-Tejero E, Sanchez J, Almaden Y, Mayer-Valor R, Rodriguez M \& Felsenfeld AJ 1996 Hysteresis of the PTH-calcium curve during hypocalcemia in the dog: effect of the rate and linearity of calcium decrease and sequential episodes of hypocalcemia. Journal of Bone and Mineral Research 11 1226-1233.

Almaden Y, Canalejo A, Ballesteros E, Añon G \& Rodriguez M 2000 Effect of high extracellular phosphate concentration on arachidonic acid production by parathyroid tissue in vitro. Journal of the American Society of Nephrology 11 1712-1718.

Almaden Y, Canalejo A, Ballesteros E, Añon G, Cañadillas S \& Rodriguez M 2002 Regulation of arachidonic acid production by intracellular calcium in parathyroid cells: effect of extracellular phosphate. Journal of the American Society of Nephrology 13 693-698.

Bas S, Aguilera-Tejero E, Estepa JC, Garfia B, Lopez I \& Rodriguez M 2002 The influence of acute and chronic hypercalcemia on the parathyroid hormone response to hypocalcemia in rabbits. European Journal of Endocrinology 146 411-418.

Blum JW, Kunz P, Rodriguez SM \& Fisher JA 1981 Parathyroid hormone response to hypocalcemia following hypercalcemia. Acta Endocrinologica 96 75-80.

Bourdeau A, Sourberbielle JC, Bonnet P, Herviaux P, Sachs CH \& Lieberherr M 1992 Phospholipase $A_{2}$ action and arachidonic acid metabolism in calcium-mediated parathyroid hormone secretion. Endocrinology 130 1339-1344.

Bradford MM 1976 A rapid and sensitive method for the quantitation of microgram quantities of protein utilizing the principle of protein-dye binding. Analytical Biochemistry 72 248-254.

Cardenas S, Ballesteros E, Gallega M \& Valcarcel M 1994 Sequential determination of triglycerides and free fatty acids in biological fluids by use of continuous pretreatment module coupled to gas chromatograph. Analytical Biochemistry 222 332-341.

Chu LLH, MacGregor RR, Anast CS, Hamilton JW \& Cohn DV 1973 Studies on the biosynthesis of rat parathyroid hormone and proparathyroid hormone: adaptation of the parathyroid gland to dietary restriction of calcium. Endocrinology 93 915-924.

Cloutier M, Gascon-Barre M \& D'Amour P 1992 Chronic adaptation of dog parathyroid function to a low calcium-high sodium-vitamin D-deficient diet. Journal of Bone and Mineral Research 7 1021-1028.

Cloutier M, Brossard JH, Gascon-Barre M \& D'Amour P 1994 Lack of involution of hyperplastic parathyroid glands in dogs: adaptation via a decrease in the calcium stimulation set point and a change in secretion profile. Journal of Bone and Mineral Research 9 621-629.

Conlin PR, Fajtova VT, Mortensen RM, Leboff MS \& Brown EM 1989 Hysteresis in the relationship between serum ionized calcium and intact parathyroid hormone during recovery from induced hyper- and hypocalcemia in normal humans. Journal of Clinical Endocrinology and Metabolism 69 593-599.

Drees BM \& Hamilton JW 1992 Pancreastatin and bovine parathyroid cell secretion. Bone and Mineral 17 335-346.

Fasciotto BH, Gorr SU, DeFranco DJ, Levine M \& Cohn DV 1989 Pancreastatin, a presumed product of chromogranin A (secretory protein-1) processing inhibits secretion from porcine parathyroid cells in culture. Endocrinology 125 1617-1622.

Fujii Y, Moreira JE, Orlando C, Maggi M, Aurbach GD, Brandi ML \& Sagaguchi K 1991 Endothelin as autocrine factor in the regulation of parathyroid cells. PNAS 88 4235-4239.

Grant FD, Conlin PR \& Brown EM 1990 Rate and concentration dependence of parathyroid hormone dynamics during stepwise changes in serum ionized calcium in normal humans. Journal of Clinical Endocrinology and Metabolism 71 370-378.

Habener JF, Kemper B \& Potts JR 1975 Calcium-dependent intracellular degradation of parathyroid hormone: a possible mechanism for the regulation of hormone stores. Endocrinology 97 431-441.

Lopez I 2002 Efecto directo del pH sobre la secrecion de hormona paratiroidea (PTH). PhD Thesis. University of Cordoba (Spain).

Mayer GP, Keaton JA, Hurst JG \& Habener JF 1979 Effects of plasma calcium concentration on the relative proportion of hormone and carboxyl fragments in parathyroid venous blood. Endocrinology 104 1778-1784.

Ritchie CK, Cohn DV, Maercklein PB \& Fitzpatrick LA 1992 Individual parathyroid cells exhibit cyclic secretion of parathyroid hormone and chromogranin-A (as measured by a novel sequential hemolytic plaque assay). Endocrinology 31 2638-2642.

Russell J, Lettieri D \& Sherwood LM 1983 Direct regulation by calcium of cytoplasmic messenger ribonucleic acid coding for pre-proparathyroid hormone in isolated bovine parathyroid cells. Journal of Clinical Investigation 72 1851-1855.

Sánchez J, Aguilera-Tejero E, Estepa JC, Almadén Y, Rodríguez M \& Felsenfeld AJ 1996 A reduced PTH response to hypocalcemia after a short period of hypercalcemia: a study in dogs. Kidney International 199650 (Suppl 57) S18-S22.

Warren HB, Lausen NCC, Segre GV, El-Hajj G \& Brown EM 1989 Regulation of calciotropic hormones in vivo in the New Zealand white rabbit. Endocrinology 125 2683-2690.

Yamamoto M, Igarashi T, Muramatsu M, Fukagawa M, Motokura T \& Ogata E 1989 Hypocalcemia increases and hypercalcemia decreases the steady-state level of parathyroid hormone messenger RNA in the rat. Journal of Clinical Investigation 83 1053-1056.

Received 20 December 2002

Accepted 7 January 2003 